\title{
Neuronal Apoptosis by Apolipoprotein E4 through Low-Density Lipoprotein Receptor-Related Protein and Heterotrimeric GTPases
}

\author{
Yuichi Hashimoto, ${ }^{1}$ Hong Jiang, ${ }^{1}$ Takako Niikura, ${ }^{1}$ Yuko Ito, ${ }^{1}$ Akari Hagiwara, ${ }^{2}$ Kazuo Umezawa, ${ }^{2}$ \\ Yoichiro Abe, ${ }^{1}$ Yoshitake Murayama, ${ }^{3}$ and Ikuo Nishimoto ${ }^{1}$ \\ ${ }^{1}$ Department of Pharmacology and Neurosciences, KEIO University School of Medicine, Shinanomachi, Tokyo 160, Japan, \\ 2Department of Applied Chemistry, Faculty of Science and Technology, KEIO University, Yokohama 223, Japan, and \\ 3Fourth Department of Medicine, University of Tokyo School of Medicine, Mejirodai, Tokyo 113, Japan
}

The $\epsilon 4$ genotype of apolipoprotein $E$ (apoE4) is the most established predisposing factor in Alzheimer's disease (AD); however, it remains unclear how apoE4 contributes to the pathophysiology. Here, we report that the apoE4 protein (ApoE4) evokes apoptosis in neuronal cells through the low-density lipoprotein receptor-related protein (LRP) and heterotrimeric GTPases. We examined neuron/neuroblastoma hybrid F11 cells and found that these cells were killed by $30 \mu \mathrm{g} / \mathrm{ml}$ ApoE4, but not by $30 \mu \mathrm{g} / \mathrm{ml}$ ApoE3. ApoE4-induced death occurred with typical features for apoptosis in time- and dose-dependent manners, and was observed in SH-SY5Y neuroblastomas, but not in glioblastomas or non-neuronal Chinese hamster ovary cells. Activated, but not native, $\alpha 2$-macroglobulin suppressed this ApoE4 toxicity. Suppression by the antisense oligonucleotide to LRP and inhibition by low nanomolar concentrations of LRP-associated protein RAP provided evidence for the involvement of LRP. The involvement of heterotrimeric GTPases was demonstrated by the findings that (1) ApoE4-induced death was suppressed by pertussis toxin (PTX), but not by heat-inactivated PTX; and (2) transfection with PTX-resistant mutant cDNAs of $\mathrm{G} \alpha_{\mathrm{i}}$ restored the toxicity of ApoE4 restricted by PTX. We thus conclude that one of the neurotoxic mechanisms triggered by ApoE4 is to activate a cell type-specific apoptogenic program involving LRP and the $G_{i}$ class of GTPases and that the apoE4 gene may play a direct role in the pathogenesis of $A D$ and other forms of dementia.

Key words: apolipoprotein E; isoform-specific action; neuronal apoptosis; lipoprotein receptor-related protein; G-proteins; pertussis toxin; Alzheimer's disease
The apoE $\epsilon 4$ allele in chromosome $19 q 13.2$ has been recognized as a susceptibility gene for late-onset Alzheimer's disease (AD) (Saunders et al., 1993; Strittmatter et al., 1993; Ueki et al., 1993; Goedert et al., 1994), AD types of dementia by diffuse Levy body disease (Helisalmi et al., 1996), and non-AD types of dementia (Helisalmi et al., 1996; Ji et al., 1998), including vascular and ischemic dementia. Inheritance of the apoE $\epsilon 4$ allele also seems to influence the pathogenesis of other neurodegenerative diseases, such as amyotrophic lateral sclerosis (Moulard et al., 1996), Pick's disease (Helisalmi et al., 1996; Kalman et al., 2000), and Parkinson's disease (Zareparsi et al., 1997; Kruger et al., 1999), although the $\epsilon 4$ association with some of them is controversial (Mui et al., 1995; Egensperger et al., 1996; The French Parkinson's Disease Genetics Study Group, 1997; Siddique et al., 1998). The gene for apoE is highly polymorphic. The common $\epsilon 3$ and $\epsilon 4$ alleles encode the isoforms of the apoE protein (ApoE): ApoE3 and ApoE4 (Zannis et al., 1982). ApoE mediates the delivery of lipids (Wilson et al., 1991) and also plays a neuron-specific role. ApoE3 stimulates neurite outgrowth, whereas ApoE4 decreases outgrowth (Nathan et al., 1994). This neurite-trophic action is mediated by the lowdensity lipoprotein receptor-related protein (LRP) (Holtzman et al., 1995; Narita et al., 1997). However, exactly how ApoE4 contributes to the development of AD remains virtually unknown.

\footnotetext{
Received July 10, 2000; revised Aug. 30, 2000; accepted Aug. 31, 2000.

This work was supported in part by grants from the Naito Foundation, Brain Science Foundation, Takeda Science Foundation, the Ministry of Health and Welfare of Japan, the Ministry of Education, Science, and Culture of Japan and the Organization for Pharmaceutical Safety and Research.

We thank K. H. Weisgraber for his kind cooperation and native ApoE proteins; M. C. Fishman for F11 neuronal hybrid cells; T. Kozasa and R. Taussig for PTXresistant G $\alpha$ cDNAs; J. T. Potts Jr, E. Ogata, and Y. \& Y. Tamai for indispensable encouragement; K. Yoshikawa for Bu695 cells; M. Morishima and Y. Ihara for SH-SY5Y cells; and E. Arakawa, D. Wylie, and K. Nishihara for expert technical assistance. We are especially indebted to T. Hiraki for cooperation in this study.

Y.H. and H.J. contributed equally to this study.

Correspondence should be addressed to Dr. Nishimoto or Dr. Murayama at the above addresses. E-mail: nisimoto@mc.med.keio.ac.jp.

Copyright (C) 2000 Society for Neuroscience $0270-6474 / 00 / 208401-09 \$ 15.00 / 0$
}

An important clue is the finding (Marques et al., 1997; Tolar et al., 1997, 1999; Jordan et al., 1998; Michikawa and Yanagisawa, 1998; DeMattos et al., 1999) that ApoE4 exerts neurotoxicity in culture. Although ApoE4-induced neurodegeneration has not yet been clearly shown in transgenic mice (Raber et al., 1998; Sun et al., 1998), it might result from in vivo suppression of ApoE4 neurotoxicity. Therefore, the molecular mechanism for ApoE4 neurotoxicity deserves investigation. Recently, Buttini et al. (2000) analyzed apoE knock-out mice that express ApoE3 or ApoE4 or both in the brain and found that ApoE4 acts as an inhibitor of neuroprotection by ApoE3.

ApoE4 binds $\mathrm{A} \beta$ and facilitates its aggregation (Strittmatter et al., 1993; LaDu et al., 1994, 1995). However, it is unlikely that this action is implicated in the ApoE4 neurotoxicity, because (1) ApoE3 binds $\mathrm{A} \beta$ at 20-fold higher levels than does ApoE4 (LaDu et al., 1994); (2) binding of $\mathrm{A} \beta$ to rabbit ApoE decreases $\mathrm{A} \beta$ toxicity in rat hippocampal neurons (Whitson et al., 1994); and (3) the N-terminal $22 \mathrm{kDa}$ fragment of ApoE4, which lacks the $\mathrm{A} \beta$ binding domain (Pillot et al., 1999), exhibits isoform-specific neurotoxicity (Marques et al., 1996, 1997; Tolar et al., 1997, 1999). Also, Demattos et al. (1999) demonstrated that ApoE4 exerts neurotoxicity not through interaction with intracellular $\mathrm{A} \beta$ or tau. The present study was conducted to examine whether ApoE4 has a direct action on neuronal death, and if so, with what molecular mechanism. We find that ApoE4 exerts isoform-specific neurotoxicity through LRP and the $\mathrm{G}_{\mathrm{i}}$ class of GTPases.

\section{MATERIALS AND METHODS}

Materials. F11 cells, described previously (Platika et al., 1985; Yamatsuji et al., 1996), were grown in Ham's F-12 (Life Technologies, Gaithersburg, MD) supplemented with $18 \%$ fetal bovine serum (FBS; HyClone, Logan, UT) and antibiotics. Bu695 cells (Hayashi et al., 1992), provided by Dr. K. Yoshikawa (Osaka University, Osaka, Japan), were grown in DMEM (Life Technologies) plus 10\% FBS and antibiotics. SH-SY5Y cells were provided by Drs. M. Morishima and Y. Ihara (University of Tokyo, Tokyo, Japan). CHO cells were described previously (Ikezu et al., 1994). ApoE3 and ApoE4 were from Chemicon (Temecula, CA). These recombinant ApoE proteins were $>95 \%$ pure, forming a single band in SDS-PAGE. Unless otherwise described, they were used as ApoE. Purified native ApoE3 and 
ApoE4 proteins (Rall et al., 1986) were kindly provided by Dr. K. H. Weisgraber (University of California, San Francisco, CA). Dimyristoylphosphatidylcholine (DMPC) was purchased from Sigma. DMPC reconstitution was performed as described previously (Innerarity et al., 1979). Pertussis toxin (PTX) was from Calbiochem-Novabiochem. For heat inactivation, PTX was incubated at $90^{\circ} \mathrm{C}$ for $1 \mathrm{hr}$. Acetyl-L-AspartylL-Glutaminyl-L-Valyl-L-Aspart-1-al (Ac-DEVD-CHO) was purchased from Peptide Institute (Mino, Osaka, Japan). $\alpha 2$-Macroglobulin $(\alpha 2 \mathrm{M})$ was from Yagai Research Center. For activation, native $\alpha 2 \mathrm{M}$ was treated with $200 \mathrm{~mm}$ methylamine in $50 \mathrm{~mm}$ Tris/ $\mathrm{HCl}, \mathrm{pH} 8.0$, and $150 \mathrm{~mm} \mathrm{NaCl}$ for $16-18 \mathrm{hr}$ at room temperature in the dark. Unreacted methylamine was removed by dialysis for $48 \mathrm{hr}$ with five changes of $20 \mathrm{~mm} \mathrm{HEPES} / \mathrm{NaOH}$, $\mathrm{pH} 7.4$, and $150 \mathrm{~mm} \mathrm{NaCl}$. The $\alpha 2 \mathrm{M}$ preparation was dialyzed again with serum-free Ham's F-12 for 4 hr. Dialyzed $\alpha 2 \mathrm{M}$ was sterilized by filtering through a $0.22 \mu \mathrm{m}$ microfilter and then stored at $4^{\circ} \mathrm{C}$ and used within 2 weeks. Enhanced green fluorescent protein (EGFP) cDNA was purchased from Clontech (Cambridge, UK) (pEGFP-N1). The cDNAs encoding $\mathrm{G} \alpha_{\mathrm{i}} \mathrm{PT}$ and $\mathrm{G} \alpha_{\mathrm{o}} \mathrm{PT}$, described previously (Taussig et al., 1992), were provided by Dr. T. Kozasa (University of Texas, Southwestern Medical Center, Dallas, TX) and Dr. R. Taussig (University of Michigan, Ann Arbor, MI). RAP and Anti-LRP antibody 8 G1 were purchased from PROGEN Biotechnic. The RAP used in this study was a rat recombinant fusion protein with $\mathrm{N}$-terminal His tag and $\mathrm{C}$-terminal c-myc tag, produced in Escherichia coli and purified by affinity beads, and similar to rat GST-fusion RAP described previously (Herz et al., 1991). The purity of the RAP fusion protein was $>95 \%$.

Oligonucleotide transfer. Antisense oligonucleotides were transferred into F11 cells using a particle bombardment-mediated gene transfer method. This was performed using the Helios Gene Gun system (Bio-Rad Hercules, CA), according to the manufacturer's instructions, as described previously in detail (Yoshida et al., 1997). Briefly, antisense oligonucleotidecoated gold particles were constructed by mixing $25 \mathrm{mg}$ gold particles $(\varnothing=$ $0.6 \mu \mathrm{m}$ ) with $100 \mu \mathrm{g}$ of antisense oligonucleotides. F11 cells were seeded at $10^{5}$ cells/well in a 12 -well plate and incubated for $24 \mathrm{hr}$ in the presence of $18 \%$ FBS. After washing, cells then underwent particle bombardmentmediated gene transfer with a gold particle/antisense oligonucleotide mixture. After culturing cells in K-PBS solution (in mM: $30.8 \mathrm{NaCl}, 120.7 \mathrm{KCl}$, $8.1 \mathrm{Na}_{2} \mathrm{HPO}_{4} \cdot 12 \mathrm{H}_{2} \mathrm{O}, 5.0 \mathrm{MgCl}_{2}, \mathrm{pH}$ adjusted to 7.4 with $\mathrm{HCl}$ ) for $2 \mathrm{hr}$, the medium was changed to Ham's F-12 plus $18 \%$ FBS, and cells were cultured for another $22 \mathrm{hr}$. Cells were then treated with ApoE4 in serumfree Ham's F-12 medium. In some experiments, introduction of antisense oligonucleotides was performed using lipofection with similar results Briefly, F11 cells were seeded at $7 \times 10^{4}$ cells/well in a six-well plate and incubated for $12-18 \mathrm{hr}$ in the presence of $18 \%$ FBS. After washing, cells were transfected with antisense oligonucleotides by lipofection (oligonucleotide, $1 \mu \mathrm{g}$; Lipofectamine, $2 \mu \mathrm{l}$; PLUS reagent, $4 \mu \mathrm{l}$ ) in the absence of serum for $3 \mathrm{hr}$, and were incubated with Ham's F-12 plus 18\% FBS for 2 hr. Next, the culture medium was changed to Ham's F-12 plus $10 \%$ FBS Twenty-four hours after the onset of transfection, cells were treated with $30 \mu \mathrm{g} / \mathrm{ml}$ ApoE and cultured with serum-free Ham's F-12, and cell mortality was measured by Trypan blue exclusion assay $72 \mathrm{hr}$ after the onset of treatment. Purified phosphorothionate-modified oligonucleotides were obtained from Sawady Technology (Tokyo, Japan). The sequence of the antisense oligonucleotide to mouse LRP (AS-LRP) mRNA corresponds to the position from -13 to +11 , which includes the ATG initiation codon (5'-GGG GTC AGC ATG GTG TGG GCC GAT- ${ }^{\prime}$ ). The scrambled oligonucleotide for the control of AS-LRP was 5'-GCG GAG GTG GTC TGG TAG ACG CGT-3'. The sequence of the antisense oligonucleotide to ApoER 2 mRNA corresponds to the position from -13 to +11 , which includes the ATG codon (5'-GGG AGG CCC ATG GCG GGC CCG GGC-3'). Because this antisense oligonucleotide is for human ApoER2 and the nucleotide sequence of rodent ApoER2 has not yet been determined, it was used as a control oligonucleotide that carries 50\% (12/24 base) identity. PTX-resistant mutant cDNAs coding for $\mathrm{G} \alpha_{\mathrm{i}} \mathrm{PT}$ or $\mathrm{G} \alpha_{\mathrm{o}} \mathrm{PT}$ were transfected using Lipofectamine PLUS (Life Technologies). In brief, F11 cells were seeded at $10^{5}$ cells/well in a six-well plate, incubated for 24 $\mathrm{hr}$ in the presence of $18 \% \mathrm{FBS}$, and mixed for $3 \mathrm{hr}$ with $10 \mu \mathrm{g}$ cDNA, 20 $\mu l$ PLUS reagent, and $25 \mu \mathrm{l}$ Lipofectamine. Adding an equal volume of Ham's F-12 plus 20\% FBS (final FBS concentration 10\%) into cultured media, cells were incubated for $24 \mathrm{hr}$. Then cells were treated with ApoE4 in fresh serum-free Ham's F-12 medium. This condition yielded $\sim 80 \%$ transfection efficiency, as assessed with EGFP cDNA.

Assays. Cell mortality was measured by Trypan blue exclusion assay as follows. Cells were seeded in 12 -well plates at a density of $10^{4}$ cells/well (when transfection was not necessary; see above for transfection experiments). After culturing these cells in complete growth medium, they were washed with serum-free medium once, and the cultured medium was changed to a fresh serum-free medium containing ApoE4 or other reagents. Two different protocols were used for this assay in the present study. (1) At the termination of experiments, cells were suspended by pipetting gently. To ensure the collection of total cells, PBS was added to the well and collected into the cell suspension, using phase-contrast microscopy, to confirm that no cells were left; $0.1 \%$ Trypan blue solution (final concentration $0.02 \%$ ) was then added to the cell suspension and incubated at $37^{\circ} \mathrm{C}$ for $1-2 \mathrm{~min}$. (2) At the termination of experiments, cells were suspended by pipetting gently, and $50 \mu \mathrm{l}$ of $0.4 \%$ Trypan blue solution was mixed with $200 \mu \mathrm{l}$ of the cell suspension (final concentration $0.08 \%$ ) at room temperature. Stained cells were counted within 3 min after mixing with Trypan blue solution. Both protocols yielded similar results. The mortality of cells was then determined as the percentage of Trypan blue-stained cells in total cells. The cell mortality assessed by these methods thus represented the population of dead cells in total cells, including both adhesive and floating cells. The basal death rates without ApoE treatment indicated the actual fraction of dead cells, but not artificial cell death occurring after cell detachment, because in situ staining of Trypan blue-positive cells indicated the presence of similar fractions of dead cells (data not shown). Cell viability was also measured by 2-(2-methoxy-4-nitrophenyl)-3-(4-nitrophenyl)-5-(2,4-disulfophenyl)-2Htetrazolium, monosodium salt (WST-8), using Cell Counting kit-8 (Wako Pure Chemicals, Tokyo, Japan). After treatment with ApoE proteins, cells were suspended, and $1 / 10$ volume $(100 \mu \mathrm{l})$ of the cell suspension was incubated with $10 \mu \mathrm{l}$ of WST-8 solution in a 96-well plate for $2 \mathrm{hr}$ at $37^{\circ} \mathrm{C}$. Absorbance of the samples at $450 \mathrm{~nm}$ wavelength was measured by Wallac 1420 ARVOsx Multi Label Counter (Amersham Pharmacia Biotech). Terminal deoxynucleotidyl transferase-mediated fluorescein-deoxy UTP nick end labeling (TUNEL) was performed using a kit (In Situ Cell Death
Figure 1. Cell toxicity of ApoE4 in F11 neuronal cells. $A$, Cell toxicity by ApoE3 and ApoE4. F11 cells were treated with ApoE4 preparations [increasing concentrations of recombinant ApoE4 (rApoE4), $30 \mu \mathrm{g} / \mathrm{ml}$ of DMPC-reconstituted ApoE4 (1) or native ApoE4 (2)] or $30 \mu \mathrm{g} / \mathrm{ml}$ of ApoE3 preparations [native ApoE3 (3), recombinant ApoE3 (4), DMPC-reconstituted ApoE3 (5), or DTT-treated ApoE3 (6)], and cell mortality was measured by Trypan blue exclusion assay. The incubation periods were $24 \mathrm{hr}$ for native ApoE proteins and $72 \mathrm{hr}$ for other cases. The values presented in all figures in this study indicate means \pm SD of at least three independent experiments. $B$, Time course of ApoE4-induced cell death, assessed by Trypan blue exclusion assay. F11 cells were treated with $30 \mu \mathrm{g} / \mathrm{ml} \mathrm{rApoE} 4$ for indicated periods, and dead cell numbers were counted in each treatment. $C$, Time courses of the toxic effects of
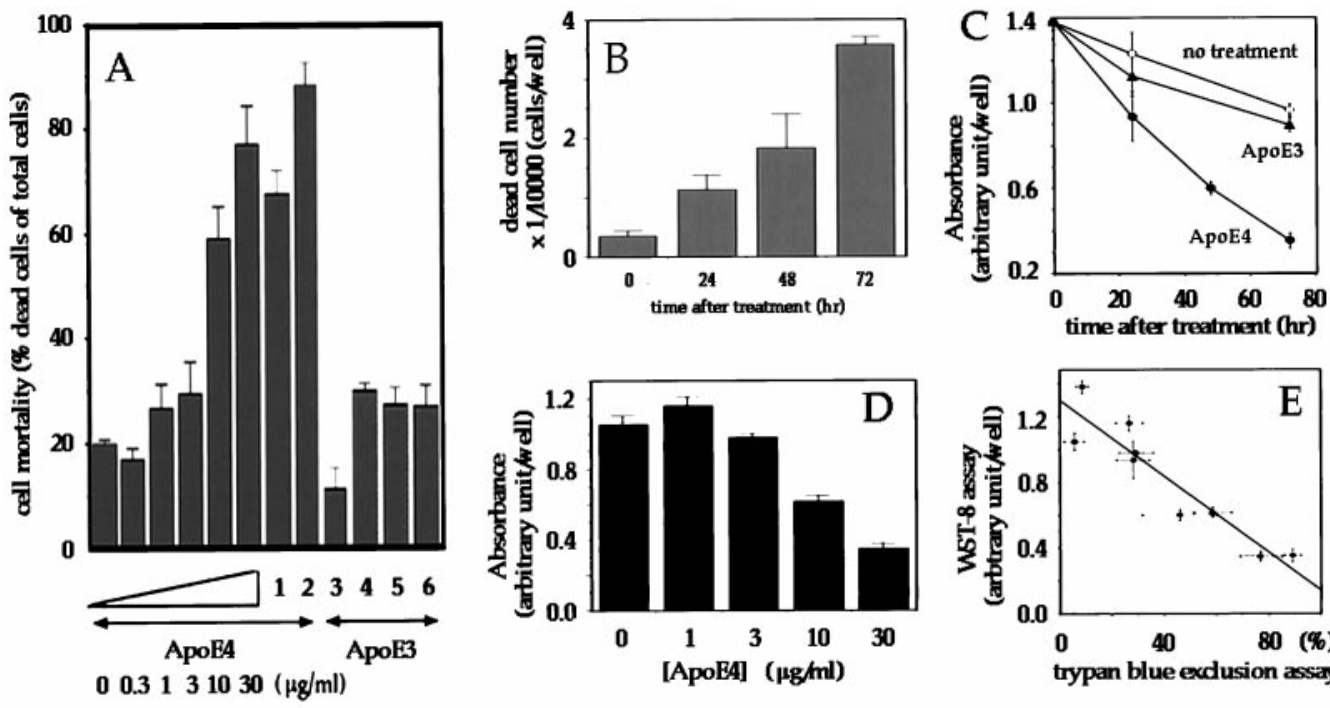

ApoE proteins, assessed by WST-8 cell viability assay. F11 cells were treated with vehicle (open circles), $30 \mu \mathrm{g} / \mathrm{ml} \mathrm{rApoE} 3$ (closed triangles), or rApoE4 (closed circles) for indicated periods, and cell viability was measured by WST-8 assay, as described in Materials and Methods. D, The dose-response relationship for the toxic effect of ApoE4. F11 cells were treated with increasing concentrations of rApoE4 for $72 \mathrm{hr}$, and cell viability was similarly measured by WST- 8 assay. E, The relationship between cell mortality assessed by Trypan blue exclusion assay and cell viability assessed by WST- 8 assay. The time course and the dose-response of the rApoE4 toxicity in F11 cells were measured by Trypan blue exclusion assay or by WST-8 assay in independently performed experiments, and corresponding data were plotted. Each value indicates means \pm SD of three measurement data (each obtained from one independent experiment, and each experiment was independently repeated three times). 
Detection Kit with Fluorescein; Boehringer Mannheim, Mannheim, Germany), according to the manufacturer's instructions. For this assay, F11 cells were seeded onto slide glasses precoated with poly-D-lysine in Ham's F-12 containing $18 \%$ FBS and antibiotics, as described previously (Yamatsuji et al., 1996). Experiments to investigate ApoE4-induced formation of the DNA ladder were performed using a kit (Takara, Japan), according to the manufacturer's instructions. Immunoblot analysis of expressed LRP was performed with $2.5 \mu \mathrm{g} / \mathrm{ml}$ anti-LRP antibody $8 \mathrm{G} 1$. Data were analyzed by Student's unpaired $t$ test. All experiments described in this study were repeated at least three times independently.

\section{RESULTS}

\section{Cell death effect of ApoE4 in F11 neuronal cells}

F11 cells are embryonic neurons immortalized by fusion of E13 rat dorsal root ganglion neurons with a mouse neuroblastoma cell line NTG18. They carry the traits of primary neurons, including the maintenance of neuronal gangliosides and the generation of action potentials (Platika et al., 1985). When F11 cells were treated with $30 \mu \mathrm{g} / \mathrm{ml}$ of recombinant ApoE4 (rApoE4) for $72 \mathrm{hr}, 70-80 \%$ of treated cells underwent cell death, as assessed by Trypan blue exclusion assay (Fig. $1 A$ ). In contrast, the same concentration of rApoE3 failed to kill F11 cells after $72 \mathrm{hr}$ treatment. Similar observations were obtained with seven different batches of rApoE4 preparations and three different batches of rApoE3 preparations. Also, essentially the same observations were obtained from purified native ApoE3 and ApoE4, except that neurotoxicity of ApoE4 occurred approximately three times more rapidly, relative to the same concentrations of rApoE4 (Fig. 1A). The toxic effect of rApoE4 was dose-dependent in a concentration range from 3 to 30 $\mu \mathrm{g} / \mathrm{ml}$. Mortality increased unidirectionally for $72 \mathrm{hr}$ when cells were treated with rApoE4 (Fig. 1B). The data for ApoE4 toxicity were reproduced when cell viability was measured by metabolic activity of viable cells, using tetrazolium salt WST-8, similar to MTT. As shown in Figure 1, $C$ and $D$, this viability assay revealed that treatment of F11 cells with rApoE4 induced time- and dosedependent decreases in cell viability, which were inversely proportional to the time- and dose-dependent increases in cell mortality assessed by Trypan blue exclusion assay (Fig. $1 E$ ).

These rApoE proteins are not able to bind to the LDL receptor (LDLR), whereas DMPC-reconstituted rApoE proteins are as potent in binding to LDLR as purified ApoE proteins (Gretch et al., 1991). We thus examined the effects of DMPC-reconstituted rApoE and found that (1) rApoE4 was as active in causing cell death as DMPC-reconstituted rApoE4; (2) DMPC-reconstituted rApoE3 was as nontoxic as native ApoE3 and rApoE3 (Fig. 1A). These data suggest that the action of $\mathrm{rApoE}$ can be generalized to native ApoE, as far as the cell death effect is concerned. The failure of DMPC-reconstituted rApoE3 to cause cell death also indicated that lack of toxicity in rApoE3 was not because of disturbed activity or inappropriate folding of $\mathrm{rApoE} 3$. This was further supported by the findings that (1) native ApoE3 was not toxic either; and (2) ApoE4-induced cell death was antagonized by rApoE3 (Table 1). As the action of ApoE3 might have been lost by potential oligomerization through Cys, we also tested the effect of DTT. We found that DTT-treated rApoE3 was also as nontoxic as native ApoE3,

\begin{tabular}{ll}
\hline Table 1. Inhibition of ApoE4-induced cell death by PTX or ApoE3 \\
& $\begin{array}{l}\text { Cell mortality } \\
\text { (\% dead cells } \\
\text { of total cells) }\end{array}$ \\
\hline ApoE3 & $10.2 \pm 5.1$ \\
ApoE4 & $74.7 \pm 2.2$ \\
ApoE4 + PTX & $25.1 \pm 6.6^{*}$ \\
ApoE4 + inactivated PTX & $73.5 \pm 11.6^{* *}$ \\
ApoE4 + ApoE3 & $30.4 \pm 10.0^{*}$
\end{tabular}

F11 cells were treated with $30 \mu \mathrm{g} / \mathrm{ml}$ ApoE4 with or without several reagents for $72 \mathrm{hr}$. Cell mortality was measured by Trypan blue exclusion. PTX was used at $1 \mu \mathrm{g} / \mathrm{ml}$; ApoE3, at $30 \mu \mathrm{g} / \mathrm{ml}$. The values indicate means \pm SE of four independent experiments.

${ }^{*} p<0.01$ and ${ }^{* *}$ not significant versus ApoE4 effect.

again indicating that the nontoxic effect of rApoE3 equals that of native ApoE3.

Because it has been reported that a high concentration $(6 \mu \mathrm{M}$, $200 \mu \mathrm{g} / \mathrm{ml})$ but not $3.2 \mu \mathrm{M}(100 \mu \mathrm{g} / \mathrm{ml})$ of ApoE3 induces significant toxicity in primary neurons (Marques et al., 1997), we also examined the toxicity of high concentrations of rApoE3. As shown in Table 2, treatment with $200 \mu \mathrm{g} / \mathrm{ml} \mathrm{rApoE3} \mathrm{resulted} \mathrm{in} \mathrm{significant}$ induction of cell death, whereas $100 \mu \mathrm{g} / \mathrm{ml}$ rApoE3 caused little toxicity. These data show that the toxicity of rApoE3 was several dozen times weaker than that of rApoE4, consistent with the study of Marques et al. (1997). Because rApoE behaved similarly to native ApoE, we thereafter analyzed the actions of $\mathrm{rApoE}$.

\section{Characterization of ApoE4-induced cell death}

Seventy-two hours after treatment with ApoE4, most dead cells had shrunk and become round, and eventually detached from plates (see Fig. 3B, bottom left panel), indicating that ApoE4 caused cells to undergo apoptosis. We thus further characterized the mode of F11 cell death induced by ApoE4. As shown in Figure $2 \mathrm{~A}, 24 \mathrm{hr}$ treatment with $30 \mu \mathrm{g} / \mathrm{ml}$ ApoE4 induced a $180 \mathrm{bp}$ ladder formation of DNA, whereas ApoE3 caused as little formation of DNA laddering as no treatment. When the cells were treated with $30 \mu \mathrm{g} / \mathrm{ml} \mathrm{ApoE} 4$ in the presence of $10 \mu \mathrm{M}$ Ac-DEVD-CHO, a specific inhibitor of caspases, DNA ladder formation in the treated cells was suppressed (Fig. $2 A$, lane 4 ), suggesting that the oligonucleosomal DNA cleavage induced by ApoE4 is a result of caspaseactivated DNase. Note that coexisting ApoE3 protected F11 cells from ApoE4-induced DNA cleavage (Fig. 2A, lane 6 ), consistent with the ApoE3 action observed by cell mortality assay (Table 1). ApoE4-induced neurotoxicity was associated with staining by TUNEL. As shown in Figure $2 B, 24 \mathrm{hr}$ treatment with $30 \mu \mathrm{g} / \mathrm{ml}$ ApoE4 remarkably increased the population of F11 cells stained by TUNEL, whereas ApoE3 treatment resulted in as little TUNEL positivity as no treatment.

In another attempt at characterization, ApoE4-induced toxicity was briefly tested in other types of cells. We examined two different

Table 2. Cell toxicity by ApoE3

\begin{tabular}{|c|c|c|c|c|}
\hline & \multicolumn{2}{|c|}{$\begin{array}{l}\text { Cell mortality } \\
\text { (\% dead cells of total cells) }\end{array}$} & \multicolumn{2}{|c|}{$\begin{array}{l}\text { Cell viability } \\
\text { (arbitrary unit/well) }\end{array}$} \\
\hline & $\mathrm{RAP}(-)$ & $\mathrm{RAP}(+)$ & $\operatorname{RAP}(-)$ & $\mathrm{RAP}(+)$ \\
\hline No treatment & $18.1 \pm 1.2$ & $\mathrm{ND}$ & $1.12 \pm 0.02$ & ND \\
\hline $100 \mu \mathrm{g} / \mathrm{ml} \mathrm{ApoE} 3$ & $18.2 \pm 0.3$ & $19.7 \pm 2.2$ & $1.12 \pm 0.04$ & $1.23 \pm 0.04$ \\
\hline $200 \mu \mathrm{g} / \mathrm{ml} \mathrm{ApoE3}$ & $31.4 \pm 3.2$ & $19.4 \pm 2.4$ & $0.71 \pm 0.03$ & $1.15 \pm 0.09$ \\
\hline
\end{tabular}

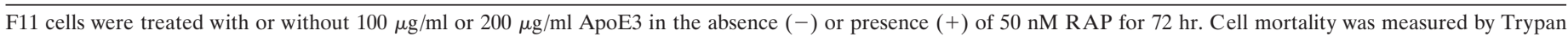

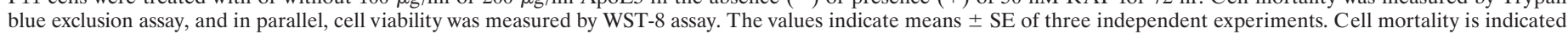
as a percentage of Trypan blue-stained cells in total cells, and cell viability is indicated as absorbance at $450 \mathrm{~nm}$ (arbitrary unit/well).

$* p<0.01$ versus no treatment, and ** $p<0.01$ versus $200 \mu \mathrm{g} / \mathrm{ml}$ ApoE3.

ND, Not determined. 
Figure 2. Characterization of ApoE4 toxicity. $A$, DNA laddering. F11 cells were treated with $30 \mu \mathrm{g} / \mathrm{ml}$ of ApoE4 (lane 2) or $30 \mu \mathrm{g} / \mathrm{ml}$ of ApoE3 (lane 3) for $24 \mathrm{hr}$. Cells were also treated with $30 \mu \mathrm{g} / \mathrm{ml}$ of ApoE4 in the presence of $10 \mu \mathrm{M}$ Ac-DEVD-CHO (lane 4), $1 \mu \mathrm{g} / \mathrm{ml}$ PTX (lane 5), or $30 \mu \mathrm{g} / \mathrm{ml}$ of ApoE3 (lane 6 ) for $24 \mathrm{hr}$. Extracted DNA was applied onto a $2 \%$ agarose gel $(2 \mu \mathrm{g} /$ lane). As another control, DNA extracted from F11 cells grown in a complete growth medium was examined for DNA ladder formation (lane 1). MK indicates a molecular marker, which is a StyI digestion product of $\lambda\left(\mathrm{CI}_{857} \mathrm{Sam} 7\right)$ DNA. This marker gives a $500-600$ bp interval in the bottom half of a gel. The results shown are representative of three similar experiments independently performed. $B$, TUNEL assay. F11 cells were treated with $30 \mu \mathrm{g} / \mathrm{ml}$ of ApoE3 or ApoE4
for $24 \mathrm{hr}$; cells were stained with TUNEL. In the bottom panels, cells were treated with $30 \mu \mathrm{g} / \mathrm{ml}$ of ApoE4 in the presence of $1 \mu \mathrm{g} / \mathrm{ml}$ PTX or $10 \mu \mathrm{M}$ Ac-DEVD-CHO for $24 \mathrm{hr}$. Phase-contrast images were superimposed on the TUNEL fluorescence images. The fragmented DNA was stained green by TdT and TUNEL. Apoptotic cells are known to undergo leakage of DNA from nuclei, which allowed cellular staining of DNA as well as nuclear staining. The results shown are representative of three similar experiments independently performed. $C$, Effect of ApoE in other cell lines. SH-SY5Y cells, Bu695 glial cells, or CHO cells were treated with or without $30 \mu \mathrm{g} / \mathrm{ml}$ of ApoE3 or ApoE4, and cell mortality was measured by Trypan blue exclusion assay. In SH-SY5Y cells, 30 $\mu \mathrm{g} / \mathrm{ml}$ of ApoE4 was also treated in the presence of $30 \mu \mathrm{g} / \mathrm{ml} \mathrm{ApoE3}$ (the extreme right lane). The incubation periods were $48 \mathrm{hr}$ for SH-SY5Y and CHO cells and 72 hr for Bu695 cells. CHO cell mortality at $72 \mathrm{hr}$ after $30 \mu \mathrm{g} / \mathrm{ml}$ ApoE4 treatment was similar to that at $48 \mathrm{hr}$ after treatment (data not shown). kinds of neural cells, SH-SY5Y and Bu695, and one non-neuronal cell line, CHO. Whereas both of the former (SH-SY5Y and Bu695) are neural, SH-SY5Y cells are neuroblastic; and Bu695 cells are glial (Hayashi et al., 1992). As shown in Figure $2 C, 30 \mu \mathrm{g} / \mathrm{ml}$ of ApoE4 failed to induce death in Bu695 cells, whereas it caused massive death in SH-SY5Y cells more rapidly than in F11 cells. Lack of toxicity by ApoE4 was also the case in non-neuronal $\mathrm{CHO}$ cells. Significant toxicity by ApoE4 was observed in SH-SY5Y cells at $24 \mathrm{hr}$ after the start of treatment, whereas ApoE3 was unable to cause death in these cells (data not shown). The inhibitory effect of ApoE3 was also noted in SH-SY5Y cells (Fig. 2C). These data indicate that ApoE4 toxicity may be specific for cells of neuroblast origin.

\section{Effect of $\alpha 2$-macroglobulin ( $\alpha 2 \mathrm{M})$ on toxic action of ApoE4}

We next examined the interfering effect of $\alpha 2 \mathrm{M}$ on the toxic effect of ApoE4. $\alpha 2 \mathrm{M}$ is another known ligand for LRP (LRP is also termed the $\alpha 2 \mathrm{M}$ receptor). For $\alpha 2 \mathrm{M}$ to bind LRP, $\alpha 2 \mathrm{M}$ must be treated with and activated by methylamine. The interaction of proteases or methylamine with $\alpha 2 \mathrm{M}$ results in its activation, a conformational change, and exposure of a latent LRP-binding site.

Whether treated with or without methylamine, $\alpha 2 \mathrm{M}$ alone showed little toxicity in F11 cells (Fig. 3). In contrast, methylaminetreated $\alpha 2 \mathrm{M}$ (activated $\alpha 2 \mathrm{M}$ or $\alpha 2 \mathrm{M}^{*}$ ) antagonized ApoE4induced cell death (Fig. $3 A$ ) and inhibited apoptotic morphological
B

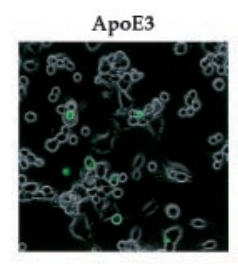

ApoE4 + Ac-DEVD-CHO

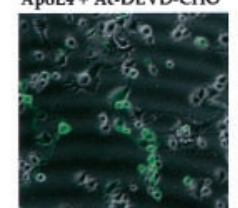

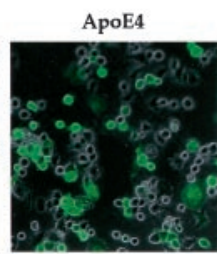

ApoE4 + PTX

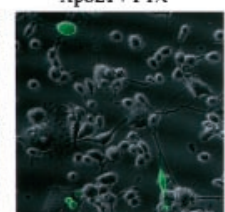

C

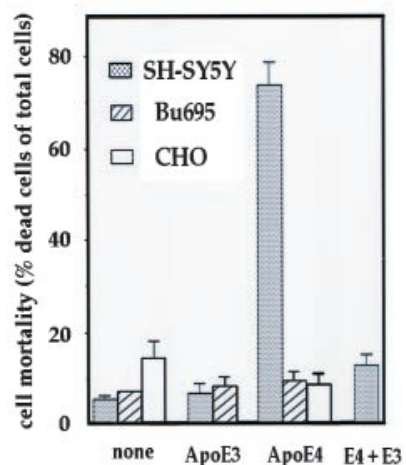

changes caused by ApoE4 treatment (Fig. $3 B$ ). Native $\alpha 2 \mathrm{M}$ either failed to suppress ApoE4-induced death or it did not protect cells from apoptotic morphological changes induced by ApoE4. These data suggest that the $\alpha 2 \mathrm{M}^{*}$ binding to LRP may affect ApoE4induced neurotoxicity.

\section{Involvement of LRP in ApoE4 neurotoxicity}

\section{Effect of antisense LRP oligonucleotide on ApoE4 toxicity}

To examine whether LRP is involved in ApoE4 toxicity, we sought to disrupt mRNA function using antisense oligonucleotides. Phosphorothionate-modified antisense oligonucleotides complementary to the translation initiation site (position -13 to +11 ) of LRP mRNA (AS-LRP) or to the translation initiation site (position -13 to +11 ) of type 2 ApoE receptor (ApoER2) mRNA, were synthesized. These oligonucleotides were designed as each crossreactivity was minimized. We introduced them by means of a particle bombardment-mediated gene transfer method. In this method, transfection efficiency evaluated by EGFP cDNA, which was introduced into F11 cells in mock-transfection under the same conditions, was at least $>60 \%$, and mostly $>80 \%$ (data not shown). Inclusion of antisense LRP oligonucleotide resulted in $>60 \%$ inhibition of ApoE4-induced mortality. On the other hand, antisense ApoER2 oligonucleotide had only marginal effects. Figure $4 A$ depicts the results of four independent series of experiments, in each of which six, six, six, and four independent transfections using
Figure 3. Inhibition of ApoE4-induced cell death by $\alpha 2 \mathrm{M}^{*}$. F11 cells were treated with either $100 \mathrm{~nm}$ activated $(a c t)$ or native $\alpha 2 \mathrm{M}, 30 \mu \mathrm{g} / \mathrm{ml}$ ApoE4, or $30 \mu \mathrm{g} / \mathrm{ml}$ ApoE4 plus 100 nM activated or native $\alpha 2 \mathrm{M}$ for $72 \mathrm{hr}$. In $A$, cell mortality was measured by Trypan blue exclusion assay; in $B$, representative phase-contrast microscopic images were presented. For both $A$ and $B$, similar experiments were performed three times with similar results.
A

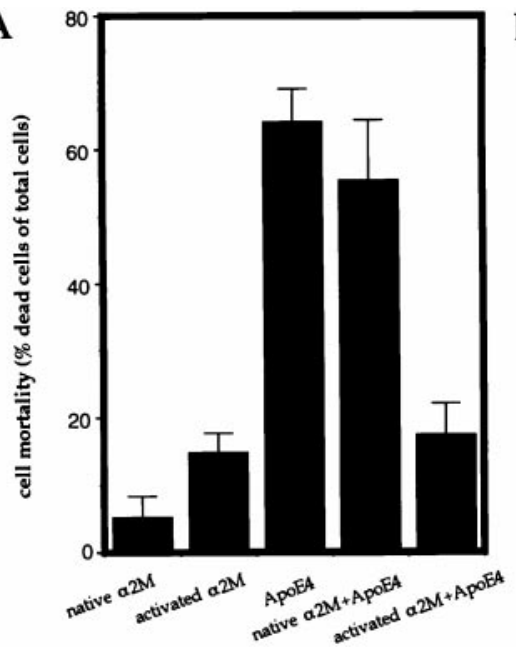

B

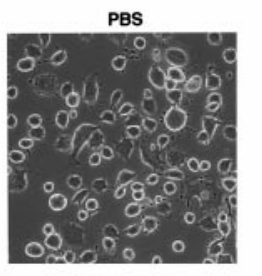

ApoE4 alone

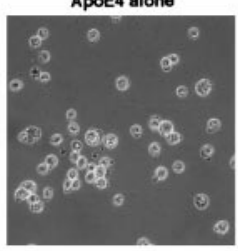

ApoE $4+$ act $a 2 M$

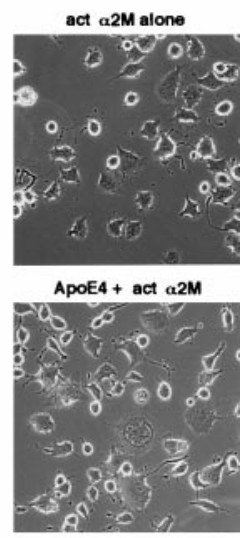


A
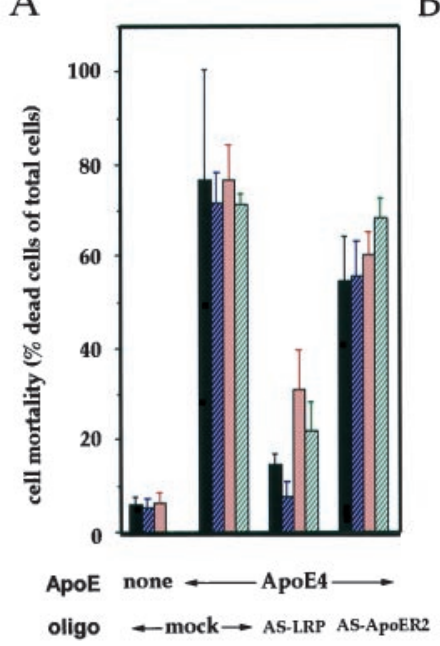

C

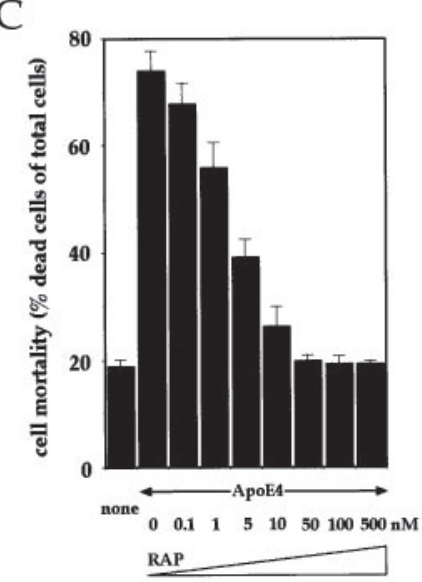

B
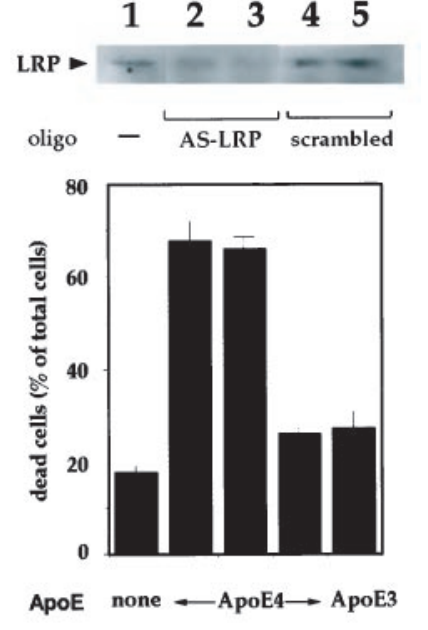

oligo no $T$ no $T$ scr AS-LRP peDNA

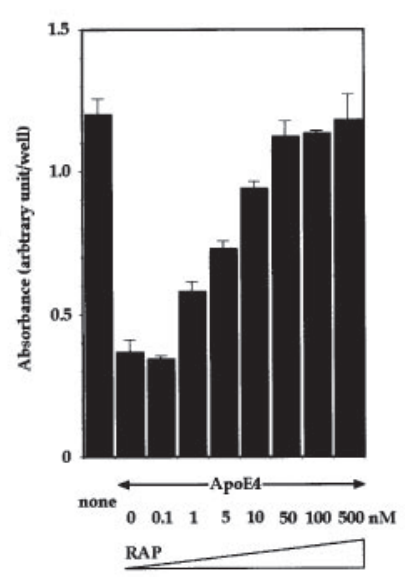

Figure 4. Evidence for the mediation by LRP of ApoE4-induced cell death. $A$, Effects of the antisense oligonucleotide to LRP or ApoER2. Twenty-four hours after either antisense oligonucleotide for LRP (ASLRP) or ApoER2 (AS-ApoER2) was transfected into F11 cells with gold particles by the gene gun system, cells were treated with $30 \mu \mathrm{g} / \mathrm{ml}$ ApoE4 for $72 \mathrm{hr}$, and cell mortality was determined by Trypan blue exclusion assay. As controls, gold particles alone were transferred into F11 cells, and cells were treated with or without $30 \mu \mathrm{g} / \mathrm{ml} \mathrm{ApoE4}$ for $72 \mathrm{hr}$ (mock). Each column indicates means $\pm \mathrm{SD}$ of four to five independent transfections performed on $1 \mathrm{~d}$. The results indicate four series of similar experiments, represented by different colors, each done on different days. In the fourth experiment, mortality was not measured in mock-transfected cells in the absence of ApoE4. B, Effects of the antisense oligonucleotide to LRP on ApoE4-induced cell mortality. F11 cells were transfected with or without AS-LRP, the scrambled oligonucleotide (scr), or pcDNA plasmid (no $T$, no transfection) and treated with $30 \mu \mathrm{g} / \mathrm{ml}$ ApoE3 or ApoE4, as described in Materials and Methods, and cell mortality was measured $72 \mathrm{hr}$ after ApoE treatment. Inset, As performed in the panel, F11 cells were transfected with AS-LRP (lanes 2,3) or a scrambled oligonucleotide (lanes 4, 5) for $12 \mathrm{hr}$ (lane 1), $48 \mathrm{hr}$ (lanes 2, 4), or $72 \mathrm{hr}$ (lanes 3, 5). Cell lysates were submitted to immunoblot analysis with anti-LRP antibody. Because ApoE4 treatment was started $24 \mathrm{hr}$ after transfection, the time point of each lane corresponds to before (lane 1), $24 \mathrm{hr}$ (lanes 2, 4), and $48 \mathrm{hr}$ (lanes 3, 5) after treatment. $C$, The dose-response relationship for the RAP suppression of ApoE4 toxicity. F11 cells were treated with or without $30 \mu \mathrm{g} / \mathrm{ml} \mathrm{ApoE4}$ in the presence or absence of increasing concentrations of recombinant RAP. Cell mortality (assessed by Trypan blue exclusion assay, left panel) and cell viability (assessed by WST- 8 assay, right panel) were measured $72 \mathrm{hr}$ after the onset of ApoE4 treatment.

a particle bombardment-mediated gene transfer method were performed under the same conditions on different days. Although the inhibition of F11 cell death by AS-LRP transfer fluctuated within a certain range in quantity, ApoE4-induced cell death was constantly and significantly inhibited by this procedure. The marginal inhibition of the ApoE4 effect by AS-ApoER2 was attributed to weak cross-reactivity of the oligonucleotides, because introduction of a

scrambled oligonucleotide resulted in no inhibition of ApoE4induced cell death (Fig. 4B). The inset of Figure $4 B$ indicates the alteration in the $515 \mathrm{kDa}$ LRP expression after transfection with AS-LRP or the scrambled oligonucleotide. Under the condition in which the cell death experiment results shown in the bottom panel of Figure $4 B$ were obtained, LRP expression decreased by $\sim 40 \%$ at $48 \mathrm{hr}$ after transfection ( $24 \mathrm{hr}$ after treatment) and by $\sim 70 \%$ at 72 hr after transfection (48 hr after treatment). In contrast, no decrease in LRP expression occurred by transfection with the scrambled oligonucleotide. Therefore, AS-LRP reduced toxicity by ApoE4 to the level of ApoE3 toxicity, whereas the scrambled oligonucleotide exerted no effect. Combined with the fact that the complementary nucleotide region of LRP corresponding to ASLRP has no homology to any known lipoprotein-binding domaincontaining receptors, these data provide evidence that LRP mediates the neurotoxicity of ApoE4.

\section{Effect of LRP-associated protein RAP}

RAP is a cell surface-associated protein that inhibits the delivery of ApoE to LRP. To confirm the involvement of LRP in the action of ApoE4, we examined the effect of RAP on ApoE4-induced death in neuronal cells. F11 cell death by ApoE4 was almost completely blocked by $50 \mathrm{~nm}$ recombinant RAP (Fig. $4 C$ ), whereas $1 \mu \mathrm{M}$ RAP alone had no effect (data not shown). In addition, both Trypan blue exclusion assay and WST-8 cell viability assay consistently revealed that RAP dose-dependently suppressed ApoE4induced neurotoxicity with an $\mathrm{IC}_{50}$ value of $\sim 5 \mathrm{~nm}$. Table 2 indicates that the weak toxicity by high concentrations of ApoE3 was also suppressed by $50 \mathrm{~nm}$ RAP. Given that the $\mathrm{IC}_{50}$ value is $1-5 \mathrm{~nm}$ for RAP to specifically inhibit the function of LRP (Herz et al., 1991), it was highly likely that the toxic action of ApoE4 (and probably that of high concentrations of ApoE3) is mediated by LRP.

\section{Involvement of PTX-sensitive GTPases in ApoE4 toxicity} Effect of PTX on the actions of ApoE4

AD-linked V642 mutants of the amyloid precursor protein (APP) cause apoptosis through the $\mathrm{G}_{\mathrm{o}}$ class of PTX-sensitive GTPases in neuronal cells (Yamatsuji et al., 1996; Giambarella et al., 1997). APP can directly interact with $\mathrm{G}_{\mathrm{o}}$ (Nishimoto et al., 1993), and V642I-APP can directly activate this G-protein in vitro (Okamoto et al., 1996). Wolozin et al. (1996) found that presenilin (PS)-2 induces apoptosis in PC12 cells in a PTX-sensitive manner, and Smine et al. (1998) showed that PS-1 activates $G_{0}$ through the C-terminal 39 residues. PS-1 and -2 are implicated in certain types of early onset familial AD. We therefore examined whether G-proteins are involved in ApoE4-induced cell death. F11 cells were treated with $30 \mu \mathrm{g} / \mathrm{ml}$ ApoE4 in the presence of $1 \mu \mathrm{g} / \mathrm{ml}$ PTX. Seventy-two hour incubation resulted in remarkable inhibition of ApoE4 action (Table 1). In contrast, heat-inactivated PTX failed to inhibit ApoE4-induced death, suggesting that the inhibitory effect of PTX was because of its enzymatic activity, not to chemicals or other contaminations in the PTX solution. Consistent with the PTX inhibition of ApoE4-induced cell mortality, the induction of DNA laddering was drastically attenuated when the cells were treated with $30 \mu \mathrm{g} / \mathrm{ml}$ ApoE4 in the presence of $1 \mu \mathrm{g} / \mathrm{ml}$ PTX (Fig. 2A, lane 5). Furthermore, PTX treatment appreciably inhibited TUNEL staining of F11 cells stimulated by $30 \mu \mathrm{g} / \mathrm{ml}$ ApoE4 (Fig. 2B). These data provide evidence that PTX-sensitive G-proteins are involved in ApoE4-induced cell death.

\section{Transfection of PTX-resistant mutants of $G_{i}$ family $G \alpha c D N A s$}

To confirm the involvement of PTX-sensitive G-proteins, we transfected PTX-resistant mutants of $\mathrm{G}_{\mathrm{i}}$ family $\mathrm{G} \alpha$ cDNA into F11 cells, treated the transfected cells with ApoE4 in the presence of PTX, and examined whether ApoE4 induced cell death in a manner resistant to PTX. Resistance to PTX is conferred on the four members of the $\mathrm{G}_{\mathrm{i}}$ family GTPases $\left(\mathrm{G} \alpha_{\mathrm{i} 1}, \mathrm{G} \alpha_{\mathrm{i} 2}, \mathrm{G} \alpha_{\mathrm{i} 3}, \mathrm{G} \alpha_{\mathrm{o}}\right)$ by the substitution of the Cys residue at the fourth position in the extreme C terminus (Taussig et al., 1992). The PTX-resistant mutants were termed $\mathrm{G} \alpha_{\mathrm{i}} \mathrm{PT}$ and $\mathrm{G} \alpha_{\mathrm{o}} \mathrm{PT}$. With or without PTX, transfection of 
Figure 5. Recovery of ApoE4 toxicity in the presence of PTX by the transfection of PTX-resistant mutants of $\mathrm{G} \alpha_{\mathrm{i}}$. A, Lack of the effect of $\mathrm{G} \alpha \mathrm{PT}$ transfection on ApoE4-induced cell death in the absence of PTX, but not in the presence of PTX. $B$, ApoE4 killed cells transfected with either $\mathrm{G} \alpha_{\mathrm{i}} \mathrm{PT}$ in the presence of PTX. Twenty-four hours after F11 cells were transfected with each PTX-resistant mutant of $\mathrm{G} \alpha_{\mathrm{i}}\left(\mathrm{G} \alpha_{\mathrm{i} 1}, \mathrm{G} \alpha_{\mathrm{i} 2}\right.$, or $\left.\mathrm{G} \alpha_{\mathrm{i} 3}\right)$ or $\mathrm{G} \alpha_{\mathrm{o}}$ or empty plasmid (vec), cells were treated with or without 30 $\mu \mathrm{g} / \mathrm{ml}$ ApoE4 in the presence or absence of 500 $\mathrm{ng} / \mathrm{ml}$ PTX for $72 \mathrm{hr}$, and mortality was measured by Trypan blue exclusion assay. The values indicate means \pm SD of six independent transfections. Similar experiments were repeated three times in total, each with essentially the same results.
A

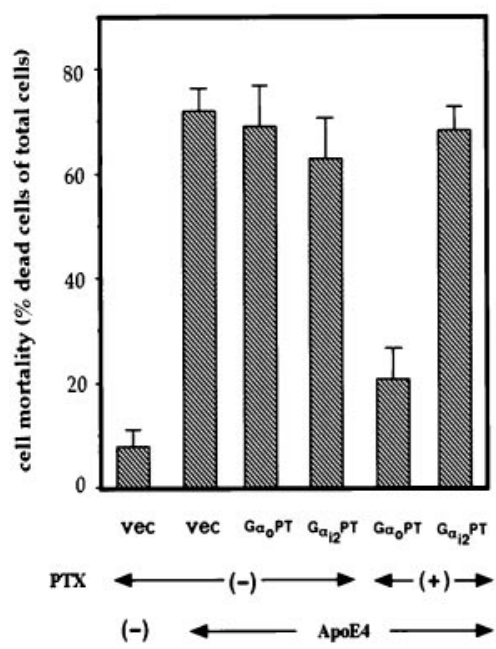

B

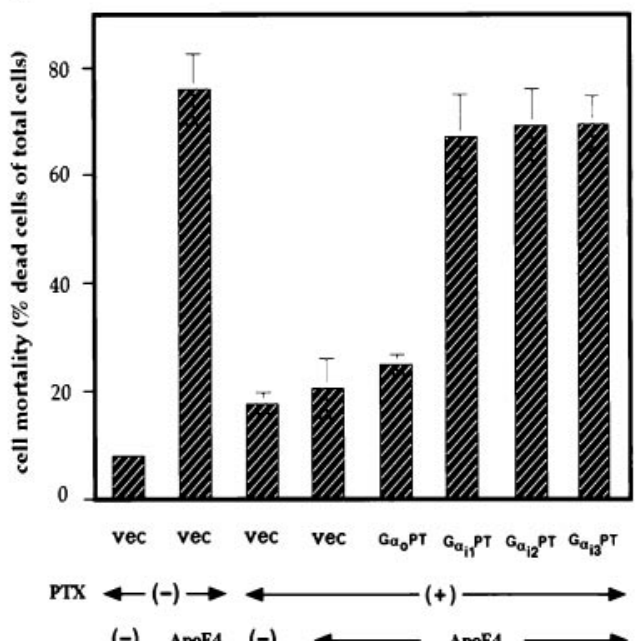

each PTX-resistant mutant cDNA did not significantly increase mortality in the absence of ApoE4, as compared with mock transfection (data not shown). In the presence of PTX, however, ApoE4 treatment killed cells transfected with either $\mathrm{G} \alpha_{\mathrm{i} 1} \mathrm{PT}, \mathrm{G} \alpha_{\mathrm{i} 2} \mathrm{PT}$, or $\mathrm{G} \alpha_{\mathrm{i} 3} \mathrm{PT}$, whereas ApoE4 could not do so in cells transfected with an empty vector or $\mathrm{G} \alpha_{\mathrm{o}} \mathrm{PT}$ (Fig. 5). Either transfection resulted in similar expression of the PTX-resistant mutants (data not shown). These data clearly indicate that ApoE4 causes cell death mediated by the PTX-sensitive $\mathrm{G}_{\mathrm{i}}$ class of GTPases.

\section{DISCUSSION}

We have herein shown that ApoE causes death in neuronal cells in an isoform-specific manner and that at least one mechanism for neurotoxic actions of ApoE4 is apoptosis mediated by LRP. The toxicity of ApoE4 was observed in cells of neuroblast origin, but not in glial cells or non-neuronal CHO cells. The observed resistance of glial cells is consistent not only with the study of Crutcher et al. (1994), indicating that glial cells are resistant to neurotoxic ApoE peptides, but also with the well established finding that LRP is found abundantly in neurons but not in glial cells (Wolf et al., 1992; Lopes et al., 1994; Tooyama et al., 1995; Fabrizi et al., 1997). Whereas this study provides additional evidence that ApoE4 is toxic in neuronal cells, discrepancies have existed in the literature. In some studies, ApoE4 causes neurotoxic effects (Marques et al., 1997; Tolar et al., 1997, 1999; Jordan et al., 1998; Michikawa and Yanagisawa, 1998; DeMattos et al., 1999), whereas in others, no toxicity has been found (Bellosta et al., 1995; Nathan et al., 1995; DeMattos et al., 1998). This variability could be attributed to several possibilities. One is that ApoE4 sensitivity of the neuronal cells used may be different not only in cell preparations but in cell conditions. Michikawa and Yanagisawa (1998) found that same neurons exhibit different responses to ApoE4 toxicity, in the presence or absence of compactin. Also, the tissue distribution (Bu et al., 1994; Zheng et al., 1994) suggests that RAP expression is differentially regulated from LRP expression, whereas their expression is mutually related (Willnow et al., 1995). It is thus conceivable that the ratio of cellular expression of RAP versus LRP, which could vary among neuronal cells and by cellular conditions, influences the toxic effects of ApoE4. Another possibility is that the culture conditions may affect ApoE4 neurotoxicity. The aforementioned studies reporting negative effects of ApoE4 were performed under conditions with serum or serum supplements including 5 $\mu \mathrm{g} / \mathrm{ml}$ of insulin, which could suppress apoptosis. In contrast, our study was performed in the complete absence of serum or other supplements.

We also found that $\alpha 2 \mathrm{M}^{*}$ suppresses ApoE4-induced neuronal death. As this suppression was observed for $\alpha 2 \mathrm{M}^{*}$, but not native $\alpha 2 \mathrm{M}$, this effect is highly likely mediated by LRP. However, it is unlikely that this suppression occurs only through inhibition by $\alpha 2 \mathrm{M}^{*}$ of ApoE4 binding to LRP, because Hussain et al. (1991) demonstrated only partial cross-competition between $\alpha 2 \mathrm{M}^{*}$ and ApoE-activated $\beta$-migrating very low-density lipoproteins for binding to LRP. Another possibility is that $\alpha 2 \mathrm{M}^{*}$ binding evokes internalization of LRP (Gliemann, 1998) and decreases the amount of cell surface LRP, resulting in impaired toxicity of ApoE4. The third possibility is that $\alpha 2 \mathrm{M}^{*}$ binding to LRP may suppress the function of LRP stimulated by another ligand ApoE4, without inhibiting the binding of ApoE4 to LRP. Such a phenomenon has been observed for another multiligand receptor, the mannose 6-phosphate/insulin-like growth factor-II receptor (Murayama et al., 1990; Takahashi et al., 1993; Ikezu et al., 1995). These possibilities are not mutually exclusive and could help to explain the nearly compete suppression of the ApoE4 effect, if they occur in combination. Whereas this is the first report that $\alpha 2 \mathrm{M}$ negatively interferes with neuronal cell death caused by AD gene products, this $\alpha 2 \mathrm{M}$ antagonism against ApoE4 concurs with recent reports (Blacker et al., 1998; Liao et al., 1998; Alvarez et al., 1999; Dodel et al., 2000; Romas et al., 2000) that polymorphisms of $\alpha 2 \mathrm{M}$ are genetically associated with $\mathrm{AD}$, although this association is controversial (Kovacs et al., 1999; Gibson et al., 2000; Higuchi et al., 2000; Sodeyama et al., 2000).

The receptors responsible for the reported neurotoxicity of ApoE have not been fully determined (Crutcher et al., 1994; Tolar et al., 1997, 1999; Jordan et al., 1998; Moulder et al., 1999). Jordan et al. (1998) argued against the mediation of ApoE4-induced neurotoxicity by LDLR family members, based mainly on their finding that RAP treatment did not inhibit the toxicity of ApoE4 in rat hippocampal neurons. In contrast, Tolar et al. (1997, 1999) indicated that RAP suppresses the toxicity of $22 \mathrm{kDa}$-terminal fragments of ApoE4, as well as full-length ApoE4, in chick lumbar sympathetic ganglions and rat hippocampal neurons, suggesting that LRP is involved in the neurotoxicity of ApoE4. Whereas the reported discrepancies might have been caused by different experimental conditions, our study provides different lines of evidence that ApoE4-bound LRP can cause neuronal cell apoptosis, although the possibility still exists that a hitherto unidentified LRPlike receptor, whose function is inhibitable by RAP and antisense LRP oligonucleotides, is responsible. Multiple groups (Lendon et al., 1997; Wavrant-DeVrieze et al., 1997, 1999; Kang et al., 1997; Kamboh et al., 1998; Hollenbach et al., 1998; Lambert et al., 1998; Beffert et al., 1999) observed the genetic association of LRP polymorphisms with AD, although this association is controversial (Clatworthy et al., 1997; Fallin et al., 1997; Baum et al., 1998; Scott et al., 1998). The involvement of LRP in ApoE4 neurotoxicity is consistent with the notion that LRP could be a risk factor for AD.

Because binding of ApoE to its receptor is usually thought to 
require lipid, the toxic action of rApoE4 in the absence of exogenous lipid was unexpected. However, Marques et al. (1997) reported that ApoE could exhibit neurotoxic effects in the absence of exogenous lipoproteins. In fact, in the present study, both rApoE3 and rApoE4 behaved similarly to DMPC-reconstituted rApoE as well as native ApoE proteins, regarding cell death. Recently, Tolar et al. (1999) reported that truncated ApoE4, which does not contain the lipid-binding domain, exerts cellular responses and toxicity from neurons through LRP, indicating that neurotoxicity by ApoE4 does not depend on lipoprotein interactions. Yu et al. (1998) also reported that lipid-free ApoE proteins are degraded by LRP. Therefore, there could be a mechanism that allows LRP to bind rApoE. In support, Demattos et al. (1998) reported that a minimally lipidated form of ApoE exhibits isoform-specific stimulation of neurite outgrowth, which has been confirmed to be mediated by LRP (Holtzman et al., 1995; Narita et al., 1997).

The molecular basis for the observed complicated actions of ApoE3 also deserves investigation. Because it is unlikely that ApoE3 binds to LRP in a manner different from that of ApoE4 binding to LRP, the binding of ApoE to LRP may not sufficiently explain the basis for the striking difference in the cytotoxic effects of these ApoE isoforms. Consider the following: (1) ApoE3 and ApoE4 share an identical LRP-binding domain; (2) low concentrations $(\leq 30 \mu \mathrm{g} / \mathrm{ml})$ of ApoE3 inhibited the toxic action of ApoE4; (3) higher concentrations $(\geq 200 \mu \mathrm{g} / \mathrm{ml})$ of ApoE3 exerted a toxic effect, probably through LRP; and (4) low concentrations ( $\leq 30$ $\mu \mathrm{g} / \mathrm{ml}$ ) of ApoE3, but not ApoE4, suppress neurotoxicity not mediated by LRP (Jordan et al., 1998). Given these facts, it is highly likely that ApoE3 may exert two opposite effects, one a neurotoxic effect through LRP, and the other a neuroprotective effect through unknown mechanisms; and that ApoE4 may only exert its neurotoxic action through LRP. Although the mechanistic basis for the neuroprotective action of ApoE3 remains unknown, both in vitro and in vivo neuroprotections by ApoE3 have been reported in the literature (Puttfarcken et al., 1997; Jordan et al., 1998; Buttini et al., 1999, 2000; Pedersen et al., 2000). Pedersen et al. (2000) argued that the neuroprotective action of ApoE3 may be through a direct lipid peroxidation-detoxifying effect allowed by the presence of one Cys residue in ApoE3, a residue absent in ApoE4.

The present study also indicates, for the first time, that ApoE4induced neurotoxicity occurs through the $G_{i}$ class of GTPases. PTX-sensitive G-proteins have been implicated in the apoptotic death of neuronal cells (Yan et al., 1995; Yamatsuji et al., 1996; Wolozin et al., 1996; Yin et al., 1997; Farkas et al., 1998; Okazawa et al., 1998). Given that transfected G $\beta 2 \gamma 2$, but not $\alpha$ subunits of PTX-sensitive G-proteins, induces DNA fragmentation in cultured cells (Giambarella et al., 1997), neurotoxicity of ApoE4 may occur through the $G \beta \gamma$ subunit released from activated $G_{i}$. A functional linkage between LRP and PTX-sensitive GTPases has so far been postulated (Misra et al., 1994, 1999; Wang and Gruenstein, 1997). Goretzki and Mueller (1998) reported that RAP-precipitated LRP associates with several G-proteins, mainly $G_{s}$ but also including $G_{i}$ to some extent. Because, in their study, LRP was probably unbound to ApoE by virtue of RAP being used for precipitation, it is tempting to examine the LRP interaction with $\mathrm{G}_{\mathrm{i}}$ in the absence of RAP and the presence of ApoE proteins. Recent studies (Yamatsuji et al., 1996; Wolozin et al., 1996; Hashimoto et al., 2000) have suggested that PTX-sensitive G-proteins act as a common target of multiple AD genes. The characterization of their downstream mechanisms would open a new avenue for the understanding and treatment of AD.

\section{REFERENCES}

Alvarez V, Alvarez R, Lahoz CH, Martinez C, Pena J, Guisasola LM, Slas-Puig J, Moris G, Uria D, Menes BB, Ribacoba R, Vidal JA, Sanchez JM, Coto E (1999) Association between an alpha(2) macroglobulin DNA polymorphism and late-onset Alzheimer's disease. Biochem Biophys Res Commun 264:48-50.

Blacker D, Wilcox MA, Laird NM, Rodes L, Horvath SM, Go RCP, Perry R, Watson Jr B, Bassett SS, McLnnis MG, Albert MS, Hyman BT, Tanzi RE (1998) $\alpha$-2 Macroglobulin is genetically associated with Alzheimer disease. Nat Genet 19:357-360.
Baum L, Chen L, Ng HK, Chan YS, Mak YT, Woo J, Chiu HF, Pang CP (1998) Low density lipoprotein receptor related protein gene exon 3 polymorphism association with Alzheimer's disease in Chinese. Neurosci Lett 247:33-36.

Beffert U, Arguin C, Poirier J (1999) The polymorphism in exon 3 of the low density lipoprotein receptor-related protein gene is weakly associated with Alzheimer's disease. Neurosci Lett 259:29-32.

Bellosta S, Nathan BP, Orth M, Dong L-M, Mahley RW, Pitas RE (1995) Stable expression and secretion of apolipoproteins E3 and E4 in mouse neuroblastoma cells produces differential effects on neurite outgrowth. J Biol Chem 270:27063-27071.

Bu G, Maksymovitch EA, Nerbonne JM, Schwartz AL (1994) Expression and function of the low density lipoprotein receptor-related protein (LRP) in mammalian central neurons. J Biol Chem 269:18521-18528.

Buttini M, Orth M, Bellosta S, Akeefe H, Pitas RE, Wyss-Coray T, Mucke L, Mahley RW (1999) Expression of human apolipoprotein E3 or E4 in the brains of Apoe-/- mice: isoform-specific effects on neurodegeneration. J Neurosci 19:4867-4880.

Buttini M, Akeefe H, Lin C, Mahley RW, Pitas RE, Wyss-Coray T, Mucke L (2000) Dominant negative effects of apolipoprotein E4 revealed in transgenic models of neurodegenerative disease Neuroscience 97: 207-210.

Clatworthy AE, Gomez-Isla T, Rebeck GW, Wallace RB, Hyman BT (1997) Lack of association of a polymorphism in the low-density lipoprotein receptor-related protein gene with Alzheimer disease. Arch Neurol 54:1289-1292.

Crutcher KA, Clay MA, Scott SA, Tian X, Tolar M, Harmony JAK (1994) Neurite degeneration elicited by apolipoprotein E peptides. Exp Neurol 130:120-126.

DeMattos RB, Curtiss LK, Williams DL (1998) A minimally lipidated form of cell-derived apolipoprotein E exhibits isoform-specific stimulation of neurite outgrowth in the absence of exogenous lipids or lipoproteins. J Biol Chem 273:4206-4212.

DeMattos RB, Thorngate FE, Williams DL (1999) A test of the cytosolic apolipoprotein $\mathrm{E}$ hypothesis fails to detect the escape of apolipoprotein $\mathrm{E}$ from the endocytic pathway into the cytosol and shows that direct expression of apolipoprotein $\mathrm{E}$ in the cytosol is cytotoxic. J Neurosci 19:2464-2473.

Dodel RC, Du Y, Bales KR, Gao F, Eastwood B, Glazier B, Zimmer R, Cordell B, Hake A, Evans R, Gallagher-Thompson D, Thompson LW, Tinklenberg JR, Pfefferbaum A, Sullivan EV, Yesavage J, Alstiel L, Gasser T, Farlow MR, Murphy Jr GM, Paul SM (2000) $\alpha 2$ Macroglobulin and the risk of Alzheimer's disease. Neurology 54:438-442.

Egensperger R, Bancher C, Kosel S, Jellinger K, Mehraein P, Graeber MB (1996) The apolipoprotein E epsilon 4 allele in Parkinson's disease with Alzheimer lesions. Biochem Biophys Res Commun 224:484-486.

Fabrizi C, Businaro R, Persichini T, Fumagalli L, Lauro GM (1997) The expression of the LDL receptor-related protein (LRP) correlates with the differentiation of human neuroblastoma cells. Brain Res 776:154-161.

Fallin D, Kundtz A, Town T, Gauntlett AC, Duara R, Barker W, Crawford F, Mullan M (1997) No association between the low density lipoprotein receptor-related protein (LRP) gene and late-onset Alzheimer's disease in a community-based sample. Neurosci Lett 233:145-147.

Farkas I, Baranyi L, Liposits ZS, Yamamoto T, Okada H (1998) Complement C5a anaphylatoxin fragment causes apoptosis in TGW neuroblastoma cells. Neuroscience 86:903-911.

Giambarella U, Yamatsuji T, Okamoto T, Matsui T, Ikezu T, Murayama Y, Levine MA, Katz A, Gautam N, Nishimoto I (1997) G protein $\beta \gamma$ complex-mediated apoptosis by familial Alzheimer's disease mutant of APP. EMBO J 16:4897-4907.

Gibson AM, Singleton AB, Smith G, Woodward R, McKeith IG, Perry RH, Ince PG, Ballard CG, Edwardson JA, Morris CM (2000) Lack of association of the $\alpha 2$-macroglobulin locus on chromosome 12 in AD. Neurology 54:433-438.

Gliemann J (1998) Receptors of the low density lipoprotein (LDL) receptor family in man. Multiple functions of the large family members via interaction with complex ligands. Biol Chem 379:951-964.

Goedert M, Strittmatter WJ, Roses A (1994) Risky apolipoprotein in brain. Nature 372:45-46.

Goretzki L, Mueller BM (1998) Low-density-lipoprotein-receptor-related protein (LRP) interacts with a GTP-binding protein. Biochem J 336:381-386.

Gretch DG, Sturley SL, Friesen PD, Beckage NE, Attie AD (1991) Baculovirus-mediated expression of human apolipoprotein E in Manduca sexta larvae generates particles that bind to the low density lipoprotein receptor. Proc Natl Acad Sci USA 88:8530-8533.

Hashimoto Y, Niikura T, Ito Y, Nishimoto I (2000) Multiple mechanisms underlie neurotoxicity by different types of Alzheimer's disease mutations of amyloid precursor protein. J Biol Chem, in press.

Hayashi Y, Kashiwagi K, Yoshikawa K (1992) Protease inhibitors generate cytotoxic fragments from Alzheimer amyloid protein precursor in cDNA-transfected glioma cells. Biochem Biophys Res Commun 187:1249-1255.

Helisalmi S, Linnaranta K, Lehtovirta M, Mannermaa A, Heinonen O, Ryynanen M, Riekkinen Sr P, Soininen H (1996) Apolipoprotein E 
polymorphism in patients with different neurodegenerative disorders. Neurosci Lett 205:61-64.

Herz J, Goldstein JL, Strickland DK, Ho YK, Brown MS (1991) 39-kDa protein modulates binding of ligands to low density lipoprotein receptorrelated protein $/ \alpha 2$-macroglobulin receptor. J Biol Chem 266:21232-21238.

Higuchi S, Matsushita S, Nakane J, Arai H, Matsui T, Urakami K, Yuzuriha $\mathrm{T}$, Takeda A (2000) $\alpha 2$-Macroglobulin gene polymorphisms show racia diversity and are not associated with Alzheimer's disease. NeuroReport 11:1167-1171.

Hollenbach E, Ackermann S, Hyman BT, Rebeck GW (1998) Confirmation of an association between a polymorphism in exon 3 of the lowdensity lipoprotein receptor-related protein gene and Alzheimer's disease. Neurology 50:1905-1907.

Holtzman DM, Pitas RE, Kilbridge J, Nathan B, Mahley RW, Bu G, Schwartz AL (1995) Low density lipoprotein receptor-related protein mediates apolipoprotein E-dependent neurite outgrowth in a central nervous system-derived neuronal cell line. Proc Natl Acad Sci USA 92:9480-9484.

Hussain MM, Maxfield FR, Mas-Oliva J, Tabas I, Ji Z-S, Innerarity TL, Mahley RW (1991) Clearance of chylomicron remnants by the low density lipoprotein receptor-related protein $/ \alpha 2$-macroglobulin receptor. J Biol Chem 266:13936-13940.

Ikezu T, Okamoto T, Murayama Y, Okamoto T, Homma Y, Ogata E, Nishimoto I (1994) Bidirectional regulation of c-fos promoter by an oncogenic gip 2 mutant of $\mathrm{G} \alpha_{\mathrm{i} 2}$ : a novel implication of retinoblastoma gene product. J Biol Chem 269:31955-31961.

Ikezu T, Okamoto T, Giambarella U, Yokota T, Nishimoto I (1995) In vivo coupling of IGF-II/M6P receptor to heteromeric G proteins: distinct roles of cytoplasmic domains and signal sequestration by the receptor. J Biol Chem 270:29224-29228.

Innerarity TL, Pitas RE, Mahley RW (1979) Binding of arginine-rich (E) apoprotein after recombination with phospholipid vesicles to the low density lipoprotein receptors of fibroblasts. J Biol Chem 254:4186-4190

Ji Y, Urakami K, Adachi Y, Maeda M, Isoe K, Nakashima K (1998) Apolipoprotein E polymorphism in patients with Alzheimer's disease, vascular dementia and ischemic cerebrovascular disease. Dement Geriatr Cogn Disord 9:243-245.

Jordan J, Galindo MF, Miller RJ, Reardon CA, Getz GS, LaDu MJ (1998) Isoform-specific effect of apolipoprotein $\mathrm{E}$ on cell survival and $\beta$-amyloid-induced toxicity in rat hippocampal pyramidal neuronal cultures. J Neurosci 18:195-204.

Kalman J, Juhasz A, Majtenyi K, Rimanoczy A, Jakab K, Gardian G, Rasko I, Janka Z (2000) Apolipoprotein E polymorphism in Pick's disease in Huntington's disease Neurobiol Aging 21: 555-558.

Kamboh MI, Ferrell RE, DeKosky ST (1998) Genetic association studies between Alzheimer's disease and two polymorphisms in the low density lipoprotein receptor-related protein gene. Neurosci Lett 244:65-68.

Kang DE, Saitoh T, Chen X, Xia Y, Masliah E, Hansen LA, Thomas RG, Thal LJ, Katzman R (1997) Genetic association of the low-density lipoprotein receptor-related protein gene (LRP), an apolipoprotein $\mathrm{E}$ receptor, with late-onset Alzheimer's disease. Neurology 49:56-61.

Kovacs T, Cairns NJ, Lantos PL (1999) $\alpha 2$-Macroglobulin intronic polymorphism is not associated with autopsy-confirmed late-onset Alzheimer's disease. Neurosci Lett 273:61-83.

Kruger R, Vieira-Saecker AM, Kuhn W, Berg D, Muller T, Kuhnl N, Fuchs GA, Storch A, Hungs M, Woitalla D, Przuntek H, Epplen JT, Schols L, Riess O (1999) Increased susceptibility to sporadic Parkinson's disease by a certain combined alpha-synuclein/apolipoprotein E genotype. Ann Neurol 45:611-617.

LaDu MJ, Falduto MT, Manelli AM, Reardon CA, Getz GS, Frail DE (1994) Isoform-specific binding of apolipoprotein $\mathrm{E}$ to $\beta$-amyloid. J Biol Chem 269:23403-23406.

LaDu MJ, Pederson TM, Frail DE, Reardon CA, Getz GS, Falduto MT (1995) Purification of apolipoprotein E attenuates isoform-specific binding to $\beta$-amyloid. J Biol Chem 270:9039-9042.

Lambert JC, Wavrant-DeVrieze F, Amouyel P, Chartier-Harlin MC (1998) Association at LRP gene locus with sporadic late-onset Alzheimer's disease. Lancet 351:1787-1788.

Lendon CL, Talbot CJ, Craddock NJ, Han SW, Wragg M, Morris JC, Goate AM (1997) Genetic association studies between dementia of the Alzheimer's type and three receptors for apolipoprotein E in a Caucasian population. Neurosci Lett 222:187-190.

Liao A, Nitsch RM, Greenberg SM, Finckh U, Blacker D, Albert M, Rebeck GW, Gomez-Isla T, Clatworthy A, Binetti G, Hock C, MuellerThomsen T, Mann U, Zuchowski K, Beisiegel U, Staehelin H, Growdon JH, Tanzi R, Hyman BT (1998) Genetic association of an $\alpha 2$ macroglobulin (Val1000Ile) polymorphism and Alzheimer's disease. Hum Mol Genet 7:1953-1956.

Lopes MBS, Bogaev CA, Gonias SL, VandenBerg SR (1994) Expression of $\alpha 2$-macroglobulin is increased in reactive and neoplastic glial cells. FEBS Lett 338:301-305.

Marques MA, Tolar M, Harmony JA, Crutcher KA (1996) A thrombin cleavage fragment of apolipoprotein $\mathrm{E}$ exhibits isoform-specific neurotoxicity. NeuroReport 7:2529-2532.

Marques MA, Tolar M, Crutcher KA (1997) Apolipoprotein E exhibits isoform-specific neurotoxicity. Alzheimer Res 3:1-6.
Michikawa M, Yanagisawa K (1998) Apolipoprotein E4 induces neuronal cell death under conditions of suppressed de novo cholesterol synthesis. J Neurosci Res 54:58-67.

Misra UK, Chu CT, Gawdi G, Pizzo SV (1994) The relationship between low density lipoprotein-related protein $/ \alpha 2$-macroglobulin $(\alpha 2 \mathrm{M})$ receptors and the newly described $\alpha 2 \mathrm{M}$ signaling receptor. J Biol Chem 269:18303-18306.

Misra UK, Gawdi G, Pizzo SV (1999) Ligation of low-density lipoprotein receptor-related protein with antibodies elevates intracellular calcium and inositol 1,4,5-trisphosphate in macrophages. Arch Biochem Biophys 372:238-247.

Moulard B, Sefiani A, Laamri A, Malafosse A, Camu W (1996) Apolipoprotein $\mathrm{E}$ genotyping in sporadic amyotrophic lateral sclerosis: evidence for a major influence on the clinical presentation and prognosis. J Neurol Sci [Suppl] 139:34-37.

Moulder KL, Narita M, Chang LK, Bu G, Johnson Jr EM (1999) Analysis of a novel mechanism of neuronal toxicity produced by an apolipoprotein E-derived peptide. J Neurochem 72:1069-1080.

Mui S, Rebeck GW, McKenna-Yasek D, Hyman BT, Brown Jr RH (1995) Apolipoprotein E epsilon 4 allele is not associated with earlier age at onset in amyotrophic lateral sclerosis. Ann Neurol 38:460-463.

Murayama Y, Okamoto T, Ogata E, Asano T, Iiri T, Katada T, Ui M, Grubb JH, Sly WS, Nishimoto I (1990) Distinctive regulation of the functional linkage between the human cation-independent mannose 6-phosphate receptor and GTP-binding proteins by insulin-like growth factor II and mannose 6-phosphate. J Biol Chem 265:17456-17462.

Narita M, Bu G, Holtzman DM, Schwartz AL (1997) The low-density lipoprotein receptor-related protein, a multifunctional apolipoprotein $\mathrm{E}$ receptor, modulates hippocampal neurite development. J Neurochem 68:587-595.

Nathan BP, Bellosata S, Sanan DA, Weisgraber KH, Mahley RW, Pitas RE (1994) Differential effects of apolipoproteins E3 and E4 on neuronal growth in vitro. Science 264:850-852.

Nathan BP, Chang K-C, Bellosta S, Brisch E, Ge N, Mahley RW, Pitas RE (1995) The inhibitory effect of apolipoprotein E4 on neurite outgrowth is associated with microtubule depolymerization. J Biol Chem 270:19791-19799.

Nishimoto I, Okamoto T, Matsuura Y, Okamoto T, Murayama Y, Ogata E (1993) Alzheimer amyloid protein precursor forms a complex with brain GTP binding protein $\mathrm{G}_{\mathrm{o}}$. Nature 362:75-79.

Okamoto T, Takeda S, Giambarella U, Matsuura Y, Katada T, Nishimoto I (1996) Intrinsic G-coupling function of amyloid precursor protein as a novel target of V642 mutations linked to familial Alzheimer disease. EMBO J 15:3769-3777.

Okazawa M, Shiraki T, Ninomiya H, Kobayashi S, Masaki T (1998) Endothelin-induced apoptosis of A375 human melanoma cells. J Biol Chem 273:12584-12592.

Pedersen WA, Chan SL, Mattson MP (2000) A mechanism for the neuroprotective effect of apolipoprotein E: isoform-specific modification by the lipid peroxidation product 4-hydroxynonenal. J Neurochem 74:1426-1433.

Pillot T, Goethals M, Najib J, Labeur C, Lins L, Chambaz J, Brasseur R, Vandekerckhove J, Rosseneu M (1999) Beta-amyloid peptide interacts specifically with the carboxy-terminal domain of human apolipoprotein E: relevance to Alzheimer's disease. J Neurochem 72:230-237.

Platika D, Boulos MH, Braizer L, Fishman MC (1985) Neuronal traits of clonal cell lines derived by fusion of dorsal root ganglia neurons with neuroblastoma cells. Proc Natl Acad Sci USA 82:3499-3503.

Puttfarcken PS, Manelli AM, Falduto MT, Getz GS, LaDu MJ (1997) Effect of apolipoprotein E on neurite outgrowth and beta-amyloidinduced toxicity in developing rat primary hippocampal cultures. J Neurochem 68:760-769.

Raber J, Wong D, Buttini M, Orth M, Bellosta S, Pitas RE, Mahley RW, Mucke L (1998) Isoform-specific effects of human apolipoprotein E on brain function revealed in ApoE knockout mice: increased susceptibility of females. Proc Natl Acad Sci USA 95:10914-10919.

Rall Jr SC, Weisgraber KH, Mahley RW (1986) Isolation and characterization of apolipoprotein E. Methods Enzymol 128:273-287.

Romas SN, Mayeux R, Rabinowitz D, Tang MX, Zadroga HR, Lantigua R, Medrano M, Tycko B, Knowles JA (2000) The deletion polymorphism and Val1000Ile in $\alpha 2$-macroglobulin and Alzheimer disease in Caribbean Hispanics. Neurosci Lett 279:133-136.

Saunders AM, Strittmatter WJ, Schmechel D, George-Hyslop PH, PericakVance MA, Joo SH, Rosi BL, Gusella JF, Crapper-MacLachlan DR, Alberts MJ, Hulette C, Crain B, Goldgaber D, Roses AD (1993) Association of apolipoprotein $\mathrm{E}$ allele $\epsilon 4$ with late-onset familial and sporadic Alzheimer's disease. Neurology 43:1467-1472.

Scott WK, Yamaoka LH, Bass MP, Gaskell PC, Conneally PM, Small GW, Farrer LA, Auerbach SA, Saunders AM, Roses AD, Haines JL, PericakVance MA (1998) No genetic association between the LRP receptor and sporadic or late-onset familial Alzheimer disease. Neurogenetics $1: 179-183$.

Siddique T, Pericak-Vance MA, Caliendo J, Hong ST, Hung WY, Kaplan J, McKenna-Yasek D, Rimmler JB, Sapp P, Saunders AM, Scott WK, Siddique N, Haines JL, Brown RH (1998) Lack of association between apolipoprotein E genotype and sporadic amyotrophic lateral sclerosis. Neurogenetics 1:213-216. 
Smine A, Xu X, Nishiyama K, Katada T, Gambetti P, Yadav SP, Wu X, Shi YC, Yasuhara S, Homburger V, Okamoto T (1998) Regulation of brain G-protein $\mathrm{G}_{0}$ by Alzheimer's disease gene presenilin-1. J Biol Chem 273:16281-16288.

Sodeyama N, Yamada M, Itoh Y, Suematsu N, Matsushita M, Otomo E, Mizusawa $\mathrm{H}$ (2000) $\alpha 2$-Macroglobulin polymorphism is not associated with AD or AD-type neuropathology in the Japanese. Neurology $54: 443-446$

Strittmatter WJ, Saunders AM, Schmechel D, Pericak-Vance M, Enghild J, Salvesen GS, Roses AD (1993) Apolipoprotein E: high-avidity binding to $\beta$-amyloid and increased frequency of type 4 allele in late-onset familial Alzheimer disease. Proc Natl Acad Sci USA 90:1977-1981.

Sun Y, Wu S, Bu G, Onifade MK, Patel SN, LaDu MJ, Fagan AM, Holtzman DM (1998) Glial fibrillary acidic protein-apolipoprotein E (apoE) transgenic mice: astrocyte-specific expression and differing biological effects of astrocyte-secreted apoE3 and apoE4 lipoproteins. J Neurosci 18:3261-3272.

Takahashi K, Murayama Y, Okamoto T, Yokota T, Ikezu T, Takahashi S, Giambarella U, Ogata E, Nishimoto I (1993) Conversion of G-protein specificity of insulin-like growth factor II/mannose 6-phosphate receptor by exchanging of a short region with b-adrenergic receptor. Proc Natl Acad Sci USA 90:11772-11776.

Taussig R, Sanchez S, Rifo M, Gilman AG, Belardetti F (1992) Inhibition of the $\omega$-conotoxin-sensitive calcium current by distinct $G$ proteins. Neuron 8:799-809.

The French Parkinson's Disease Genetics Study Group (1997) Apolipoprotein E genotype in familial Parkinson's disease. J Neurol Neurosurg Psychiatry 63:394-395.

Tolar M, Marques MA, Harmony JAK, Crutcher KA (1997) Neurotoxicity of the $22 \mathrm{kDa}$ thrombin-cleavage fragment of apolipoprotein $\mathrm{E}$ and related synthetic peptides is receptor-mediated. J Neurosci 17:5678-5686.

Tolar M, Keller JN, Chan S, Mattson MP, Marques MA, Crutcher KA (1999) Truncated apolipoprotein E (apoE) causes increased intracellular calcium and may mediate apoE neurotoxicity. J Neurosci 19:7100-7110.

Tooyama I, Kawamata T, Akiyama H, Kimura H, Moestrup SK, Gliemann J, Matsuo A, McGeer PL (1995) Subcellular localization of the low density lipoprotein receptor-related protein ( $\alpha 2$-macroglobulin receptor) in human brain. Brain Res 691:235-238.

Ueki A, Kawano M, Namba Y, Kawakami M, Ikeda K (1993) A high frequency of apolipoprotein E4 isoprotein in Japanese patients with late-onset nonfamilial Alzheimer's disease. Neurosci Lett 163:166-168.

Yamatsuji T, Okamoto T, Takeda S, Fukumoto H, Iwatsubo T, Suzuki N, Asami-Odaka A, Ireland S, Kinane TB, Nishimoto I (1996) Neuronal DNA fragmentation by familial Alzheimer's V642 mutants of APP via heteromeric G proteins. Science 272:1349-1352.

Yan GM, Lin SZ, Irwin RP, Paul SM (1995) Activation of G proteins bidirectionally affects apoptosis of cultured cerebellar granule neurons. J Neurochem 65:2425-2431.

Yin DL, Ren XH, Zheng ZL, Pu L, Jiang LZ, Ma L, Pei G (1997) Etorphine inhibits cell growth and induces apoptosis in SK-N-SH cells: involvement of pertussis toxin-sensitive $G$ proteins. Neurosci Res 29:121-127.

Yoshida Y, Kobayashi E, Endo H, Hamamoto T, Yamanaka T, Fujimura A, Kagawa Y (1997) Introduction of DNA into rat liver with a hand-held gene gun: distribution of the expressed enzyme, $\left.{ }^{32} \mathrm{P}\right] \mathrm{DNA}$, and $\mathrm{Ca}^{2+}$ flux. Biochem Biophys Res Commun 234:695-700.

Yu L, Narita M, Bu G, Schwartz A, Holtzman D (1998) Lipid free apoE3 and apoE4 are differentially degraded via cellular LRP. Soc Neurosci Abstr 24:1712.

Wang XS, Gruenstein E (1997) Rapid elevation of neuronal cytoplasmic calcium by apolipoprotein E peptide. J Cell Physiol 173:73-83.

Wavrant-DeVrieze F, Perez-Tur J, Lambert JC, Frigard B, Pasquier F, Delacourte A, Amouyel P, Hardy J, Chartier-Harlin MC (1997) Association between the low density lipoprotein receptor-related protein (LRP) and Alzheimer's disease. Neurosci Lett 227:68-70.

Wavrant-DeVrieze F, Lambert JC, Stas L, Crook R, Cottel D, Pasquier F, Frigard B, Lambrechts M, Thiry E, Amouyel P, Tur JP, Chartier-Harlin MC, Hardy J, Van Leuven F (1999) Association between coding variability in the LRP gene and the risk of late-onset Alzheimer's disease. Hum Genet 104:432-434.

Whitson JS, Mims MP, Strittmatter WJ, Yamaki T, Morrisett JD, Appel SH (1994) Attenuation of the neurotoxic effect of $A \beta$ amyloid peptide by apolipoprotein E. Biochem Biophys Res Commun 199:163-170.

Willnow TE, Armstrong SA, Hammer RE, Herz J (1995) Functional expression of low density lipoprotein receptor-related protein is controlled by receptor-associated protein in vivo. Proc Natl Acad Sci USA 92:4537-4541.

Wilson C, Wardell MR, Weisgraber KH, Mahley RW, Agard DA (1991) Three-dimensional structure of the LDL receptor-binding domain of human apolipoprotein E. Science 252:1817-1822.

Wolf BB, Lopes MBS, VandenBerg SR, Gonias SL (1992) Characterization and immunohistochemical localization of $\alpha 2$-macroglobulin receptor (low-density lipoprotein receptor-related protein) in human brain. Am J Pathol 141:37-42.

Wolozin B, Iwasaki K, Vito P, Ganjei JK, Lacana E, Sunderland T, Zhao B, Kusiak JW, Wasco W, D'Adamio L (1996) Participation of presenilin 2 in apoptosis: enhanced basal activity conferred by an Alzheimer mutation. Science 274:1710-1713.

Zannis VI, Breslow JL, Utermann G, Mahley RW, Weisgraber KH, Havel RJ, Goldstein JL, Brown MS, Schonfeld G, Hazzard WR, Blum C (1982) Proposed nomenclature of apoE isoproteins, apoE genotypes, and phenotypes. J Lipid Res 23:911-914.

Zareparsi S, Kaye J, Camicioli R, Grimslid H, Oken B, Litt M, Nutt J, Bird T, Schellenberg G, Payami H (1997) Modulation of the age at onset of Parkinson's disease by apolipoprotein E genotypes. Ann Neurol 42:655-658.

Zheng G, Bachinsky DR, Stamenkovic I, Strickland DK, Brown D, Andres G, McCluskey RT (1994) Organ distribution in rats of two members of the low-density lipoprotein receptor gene family, gp330 and LRP/alpha $2 \mathrm{MR}$, and the receptor-associated protein (RAP). J Histochem Cytochem 42:531-542. 